\title{
Comparison of the Clinical Recovery after Nerve Defect Reconstruction Using 4 Different Methods - Experimental Model
}

Andrei MARIN', Anica DRICU², Georgiana Gabriela MARIN³ ${ }^{3}$ Carmen GIUGLEA ${ }^{1,4}$

\begin{abstract}
There are several possibilities for repairing a nerve defect. These include nerve grafting, tissues for bridging, biological or synthetic nerve conduits. Such conduits, alone or filled with different tissues or substances, may be the key for a major breakthrough in the modern treatment of nerve defects. The easiest way to research these new methods is by experimental in vivo research on live animals - such as the Wistar rats. The following article aims to compare 4 different types of repairs for nerve defects: the nerve graft, a biologic nerve conduit (rat aorta), rat aorta with platelet rich plasma and rat aorta with stem cells.
\end{abstract}

Keywords: peripheral nerve reconstruction, experimental microsurgery, stems cells, platelet rich plasma, nerve conduit.

\section{Rezumat}

Printre posibilitățile de reparare a unui defect nervos se numără - grefa de nerv, utilizarea a diverse țesuturi pentru a umple spațiul gol dintre capetele nervoase în combinație cu conductori nervoși sintetici sau biologici. Astfel de conductori pot fi utilizați fără sau împreună cu diverse substanțe sau soluții, acestea putând aduce un aport semnificativ procesului de regenerare nervoasă. Metoda de experimentare in vivo pe animale de laborator precum șobolanii Wistar, reprezintă cea mai bună cale de a cerceta eficacitatea acestor terapii. Următorul articol urmărește compararea a 4 metode diferite de reparare a unui defect nervos - prin grefa de nerv, folosind un conduct biologic (aorta de sobolan), folosind aorta in combinatie cu plasma îmbogățită în trombocite și aorta umplută cu celule stem.

Cuvinte cheie: reconstrucție nervoasă periferică, microchirurgie experimentală, celule stem, plasmă îmbogățită în trombocite, conductor nervos.

Department of Plastic Surgery, „Sf. Ioan” Emergency Hospital, Bucharest, Romania

${ }^{2}$ Department of Biochemistry, University of Medicine and Pharmacy, Craiova, Romania

${ }^{3}$ Department of Cardiology, „Prof. Dr. C.C. Iliescu” Emergency Institute for Cardiovascular Diseases, Bucharest, Romania

${ }^{4}$ „Carol Davila” University of Medicine and Pharmacy, Bucharest, Romania

\section{Corresponding author.}

Radu Mihail MIRICA, „Sf. Ioan" Emergency Clinical Hospital, „Carol Davila" University of Medicine and Pharmacy, Bucharest, Romania. E-mail: mirica_rm@yahoo.com 


\section{INTRODUCTION}

Experimental nerve microsurgery represents a real challenge, not because it is hard to perform, but rather because the results can be tardily acknowledged. This implies a great deal of effort, as the results must be measured in dynamics, at different intervals of time, in order to point out a precise moment of recovery.

The challenge is even greater when it comes to nerve defects, as there are several methods for bridging the gap, each method having its own benefits as well as shortcomings. Since clinical experiments are difficult to perform because they require similar circumstances to be fairly evaluated and compared, experimental in vivo injuries on animals can be reproduced in order to achieve similar circumstances so that the evaluation and comparison could be accurately performed.

Nerve defects up to $3 \mathrm{~cm}$ are suitable candidates for a nerve graft ${ }^{1,2}$. Considered to be golden standard, there are other possibilities for replacing the nerve graft in order to bridge nerve gaps. These include different types of conduits - either biologic or synthetic. To improve the outcomes by increasing the speed of nerve regeneration, several biological substances or tissues have been used in different experiments - degenerated muscles, adipose tissue or platelet rich plasma $a^{3-5}$.

Rat sciatic nerve is frequently used when evaluating nerve regeneration technics. This is due to the fact that that Wistar rats are affordable, easy to manipulate; they require lodging facilities which can be more easily to obtain and the anesthesia is easy to perform ${ }^{6,7}$. The most important aspects however are the high similitude between the human and the sciatic nerves as well as the fact that the rat sciatic nerve has a considerable size and length in order to perform different surgical procedures $^{8}$.

The sciatic nerve of the rat divides into 3 main branches, although there may be some varieties to its anatomy. These branches are from superior to inferior: common peroneal nerve, tibial nerve and sural nerve ${ }^{9}$.

When evaluating the results of nerve recovery, one must measure sensibility and movement. There are special tests which can be performed on the animals included in the experiment to evaluate these abilities.

Platelet rich plasma is well known to contain many growth factors which aid recovery after injury. Studies have shown its contribution to healing skin ulcers, bone defects or even distraction osteogenesis ${ }^{10}$. More

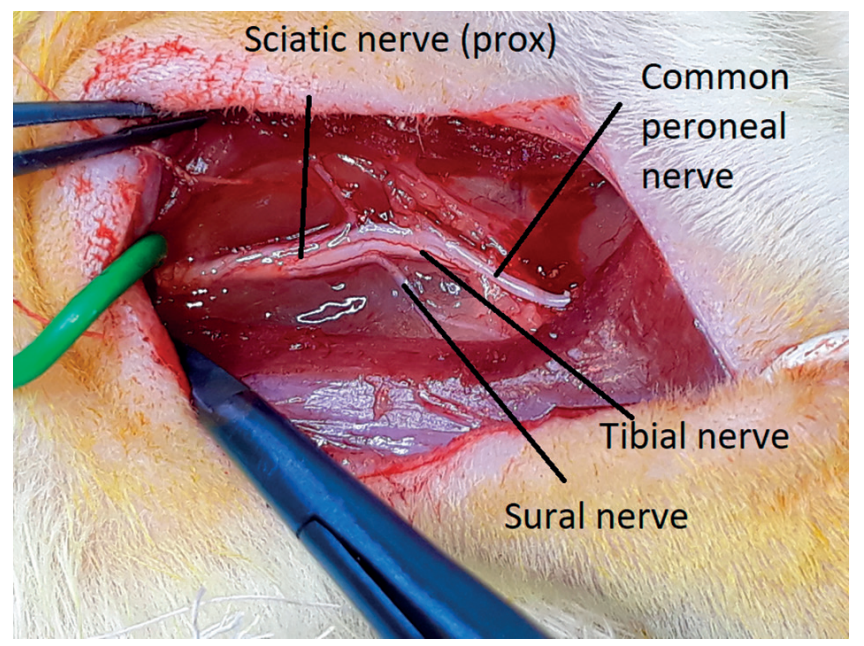

recent studies have shown that PRP has improved nerve regeneration after injury ${ }^{11-14}$.

The thrombocytes are fragments of cytoplasm of the megakaryocytes with a diameter of 2 microns ${ }^{15-16}$. The platelets contain over 30 active bioproteins with roles in hemostasis and regeneration ${ }^{17} .7$ proteins initiate all active regeneration processes and 3 proteins act as adhesion molecules - vitronectine, fibronectine and fibrin ${ }^{18,19}$.

\begin{tabular}{|c|c|}
\hline $\begin{array}{l}\text { Platelet Growth } \\
\text { Factor Type }\end{array}$ & Source \\
\hline $\begin{array}{l}\text { PDGF a-b (platelet } \\
\text { derived growth factor) }\end{array}$ & $\begin{array}{l}\text { Platelets, endothelial cells, } \\
\text { osteoblasts, smooth muscle cells, } \\
\text { monocytes, macrophages }\end{array}$ \\
\hline $\begin{array}{l}\text { TGF a-b (transforming } \\
\text { growth factor) }\end{array}$ & $\begin{array}{l}\text { Platelets, cartilage/bone matrix, NK } \\
\text { cells, macrophages/monocytes, } \\
\text { neutrophils }\end{array}$ \\
\hline $\begin{array}{l}\text { VEGF (vascular } \\
\text { endothelial growth } \\
\text { factor) }\end{array}$ & Platelets, endothelial cells \\
\hline $\begin{array}{l}\text { EGF (epidermal growth } \\
\text { factor) }\end{array}$ & Platelets, macrophages/monocytes \\
\hline $\begin{array}{l}\text { FGF (fibroblast growth } \\
\text { factor) }\end{array}$ & $\begin{array}{l}\text { Platelets, chondrocytes, osteoblasts, } \\
\text { macrophages }\end{array}$ \\
\hline $\begin{array}{l}\text { IGF-1 (Insulin growth } \\
\text { factor 1) }\end{array}$ & $\begin{array}{l}\text { Fibroblasts, osteoblasts, smooth } \\
\text { muscle cells, endothelial cells }\end{array}$ \\
\hline $\begin{array}{l}\text { CTGF (connective tissue } \\
\text { growth factor) }\end{array}$ & Platelets in bone marrow \\
\hline
\end{tabular}

Active bioproteins which initiate regenerative process ${ }^{20}$

The stem cells secrete growth factors and proteins which form the lamina basalis, thus contributing to nerve regeneration ${ }^{21,22}$. The neurotrophic molecules produced 
by the mesenchymal stem cells can delay cellular death, at the same time taking part in the regeneration of the neural tissue $\mathrm{e}^{23-28}$.

Stem cells exercise their regenerative effects by releasing growth factors and other soluble mediators which act on target cells creating a proper microenvironment for nerve regeneration ${ }^{29-31}$.

\section{Material and method}

The conducted experiment represents part of a $\mathrm{PhD}$ thesis, in which several methods for nerve defects have been compared. The active legislation for animal experimentation was followed.

42 male Wistar rats were used for this experiment, with similar age and weight. 2 rats were used to harvest biological tissues for the experiments (the aortas to be used as vascular conduits and blood to obtain platelet rich plasma).

The 40 remaining rats were equally divided into the 4 groups and they were all operated on the right sciatic nerve. The 4 methods considered for comparison were:

1. $1^{\text {st }}$ lot - nerve allograft (autograft)

2. $2^{\text {nd }}$ lot - simple vascular conduct - rat aorta

3. $3^{\text {rd }}$ lot - rat aorta filled with platelet rich plasma (PRP)

4. $4^{\text {th }}$ lot - rat aorta filled with mesenchymal stem cells.

2 rats from the first group were excluded from the study, one due to postoperative death, the other one due to nerve rupture at the suture site.

Table 1. General presentation of the groups

\begin{tabular}{|c|c|c|c|c|c|}
\hline $\mathbf{n = 3 8}$ & Lot 1 & Lot 2 & Lot 3 & Lot 4 & Total \\
\hline Variable & $\begin{array}{c}\text { Median } \\
\text { (IQR) }\end{array}$ & $\begin{array}{c}\text { Median } \\
\text { (IQR) }\end{array}$ & $\begin{array}{c}\text { Median } \\
\text { (IQR) }\end{array}$ & $\begin{array}{c}\text { Median } \\
\text { (IQR) }\end{array}$ & $\begin{array}{c}\text { Median } \\
\text { (IQR) }\end{array}$ \\
\hline Age (days) & $52(4)$ & $51(1)$ & $55(2)$ & $60(2)$ & $55(9)$ \\
\hline $\begin{array}{c}\text { Weight } \\
\text { (grams) }\end{array}$ & $269(28)$ & $245(18)$ & $250(5)$ & $298(30)$ & $\begin{array}{c}258.5 \\
(34)\end{array}$ \\
\hline
\end{tabular}

The anesthetic used was a mixture of $75-100 \mathrm{mg} /$ $\mathrm{kg}$ ketamine with $10 \mathrm{mg} / \mathrm{kg}$ xylazine, injected into the peritoneum ${ }^{32}$. This provided a good muscle relaxation, as well as analgesia and suppressor of visceral reflexes.
Before cutting the sciatic nerve to create the defect, drops of lidocaine were added at the future injury site to ensure proper analgesia.

Surgical intervention. After properly shaving the posterior area around the gluteus and the biceps femur, an incision was made $0.5 \mathrm{~cm}$ inferior to the femur. The dissection through the fibers of the biceps femur muscle followed an oblique line (from superomedial to infero-lateral). The sciatic nerve was located immediately beneath the biceps muscle in this region.

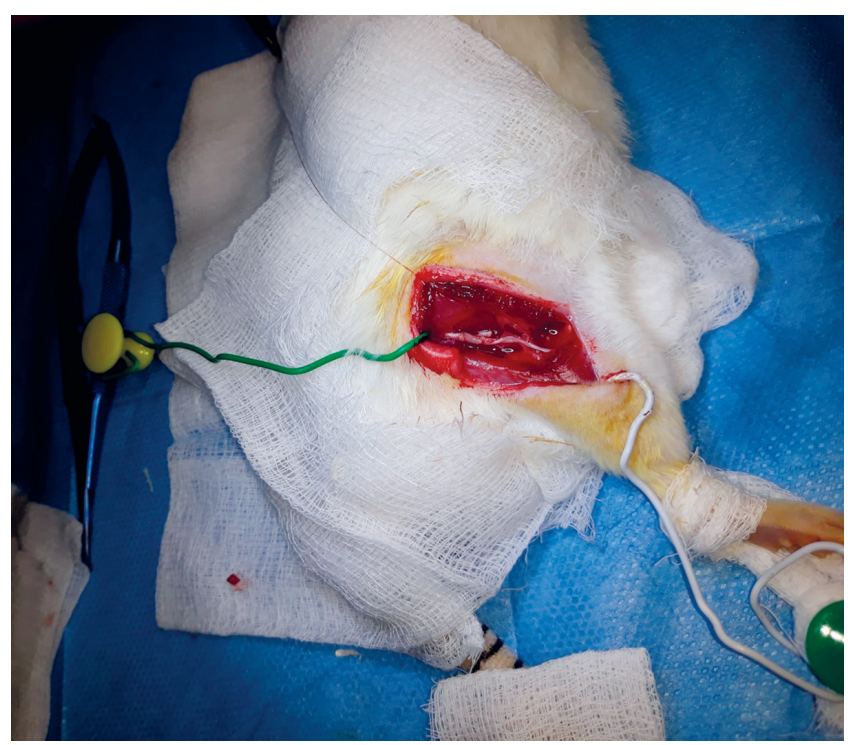

Sciatic nerve exposure

After nerve exposure, the nerve was incised proximal to the bifurcation in order to achieve a $0.5 \mathrm{~cm}$ nerve graft. For the first batch, the nerve graft was sutured in situ in its original place. For batches $2-4$, the nerve graft was discarded and replaced with a segment of rat aorta, which was used as a nerve conductor.

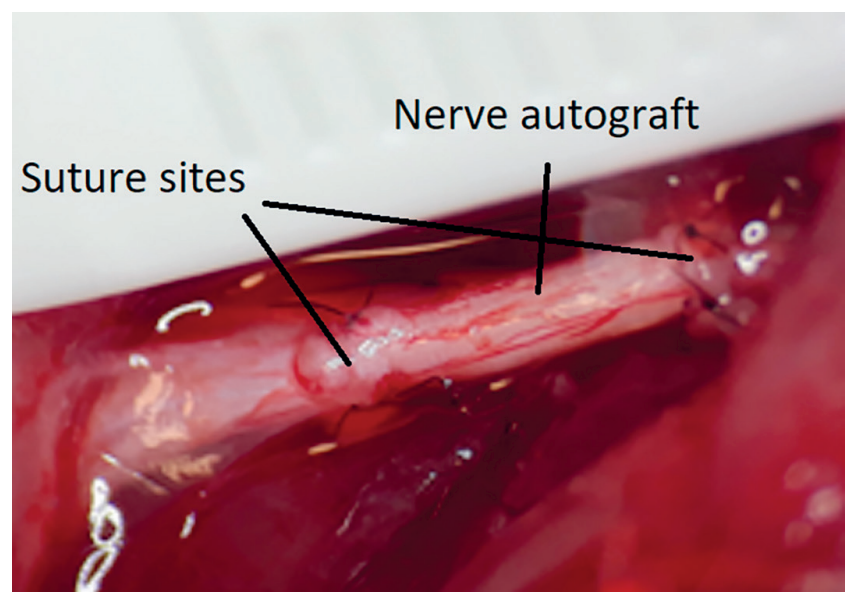

$1^{\text {st }}$ batch. Nerve graft sutured in situ 
The rat aorta was harvested from its emergence from the heart to its bifurcation into the common iliac arteries. Each rat aorta was used for a number of 10 procedures by dividing each aorta in equal lengths in order to supply nerve conduits for an entire batch.

The rat which died in the first batch was excluded from the study but was used to harvest its aorta for the second batch. By doing so, only 2 separate rats were sacrificed for biological materials (for batches 3 and 4). The aortas were preserved in saline solution for the duration of the 10 operations.

One aortic nerve conduit was about $0.6-0.7 \mathrm{~cm}$, which was long enough to match the $0,5 \mathrm{~cm}$ nerve defect. The nerve endings were sutured inside the aortic nerve conduit so that there was an overlapping surface of $\sim 0.1 \mathrm{~cm}$ on each side.

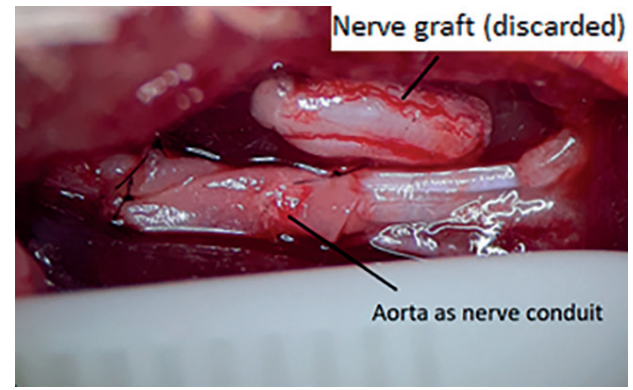

$2^{\text {nd }}$ batch. Aorta as nerve conduit

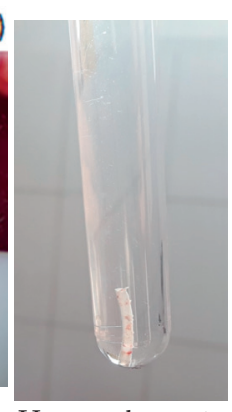

Harvested aorta in saline solution
For the $3^{\text {rd }}$ batch, blood was harvested for PRP from the 2 rats which were sacrificed. The harvest was performed after the rats were heavily sedated with an overdose of the anesthetic mixture. After a small sternotomy, intracardiac blood was taken using a $5 \mathrm{ml}$ syringe.

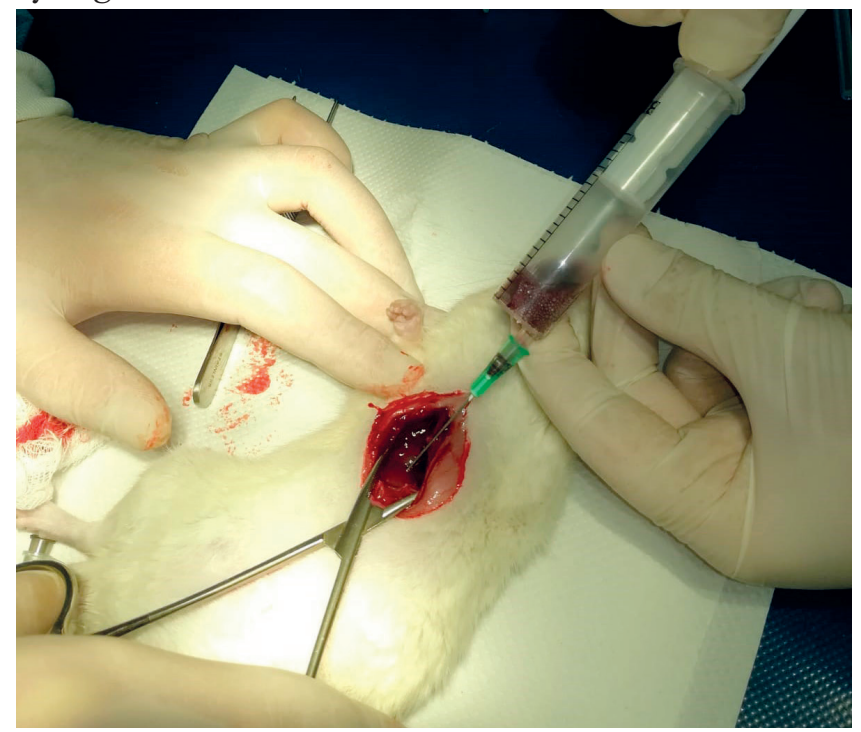

Because the platelets in the blood sample have a short life spam, all interventions using the same PRP solution were performed during the same day. For this reason, the rats in batch 3 were operated in 2 different days (5/day) with the PRP solution freshly prepared earlier in the day.

After harvest, the blood was transferred inside a special vacuum tube, which contained a separating gel and sodium citrate. Sodium citrate is a useful anticoagulant which acts by calcium chelation preventing platelet aggregation. After 5 minutes in a small centrifuge at $4000 \mathrm{rpm}$ for 5 minutes, the supernatant containing PRP solution was transferred into a syringe.

After suturing the aortic conduit at proximal stump of the sectioned nerve, few drops of the PRP solution were "spilled" inside the biologic nerve conduit using the syringe and then the distal stump was sutured at the aortic conduit in a manner so that the PRP inside the aortic conduit not to leak out.

Because some spillage was inevitable, before placing the final suture on the distal stump, a few more drops of PRP were placed inside the aortic tube, in order to have it as full as possible.

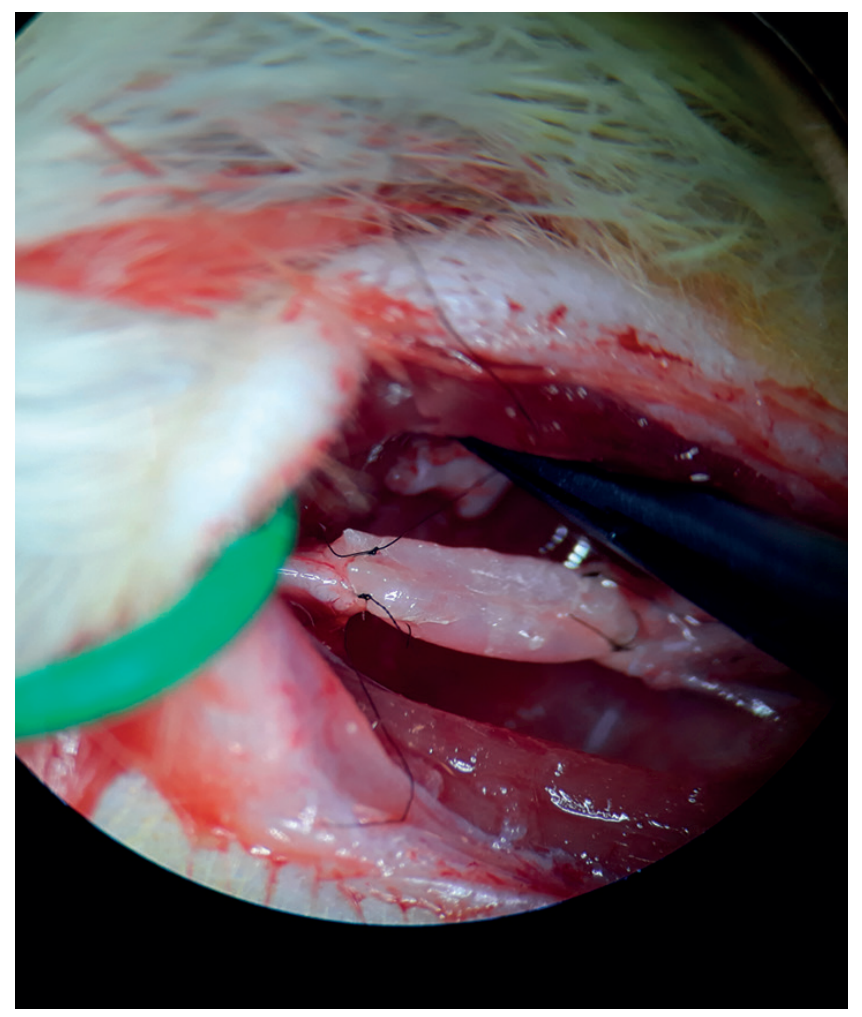

Aortic conduit with PRP inside it 
In the $4^{\text {th }}$ batch, instead of the PRP solution, human mesenchymal stem cells from the umbilical cord were used. These stem cells were conserved in liquid nitrogen and were provided from another research study.

The transport and preservation conditions of these stem cells were rigorous - immersed in liquid nitrogen at a temperature of $-196^{\circ}$ Celsius and at high pressure, the transport recipient contained enough liquid nitrogen for a period of 2-3 days ${ }^{33}$.

After defrosting, the stem cells had a short life spam (few hours). 2 different cryovials containing these cells were needed in order to operate the $4^{\text {th }}$ batch on 2 separate consecutive days.

The defrosting protocol of the stem cells:

1. Sterile conditions were used for the process.

2. The cryogenic tube was extracted from $-196^{\circ} \mathrm{C}$.

3. $500 \mu \mathrm{L}$ PBS (phosphate-buffered saline) was immediately added and the solution was gently stirred.

4. The solution was centrifuged at $1500 \mathrm{rpm}$ for 5 minutes.

5. The supernatant was removed.

6. Another $500 \mu \mathrm{L}$ PBS was added and the solution was gently stirred.

7. The solution was centrifuged at $1500 \mathrm{rpm}$ for 5 minutes.

8. The supernatant was removed again.

9. The cells were suspended in Ringer solution.

The operations of the $4^{\text {th }}$ batch followed the protocol for the $3^{\text {rd }}$ batch, with the difference that instead of PRP, stem cells were used.

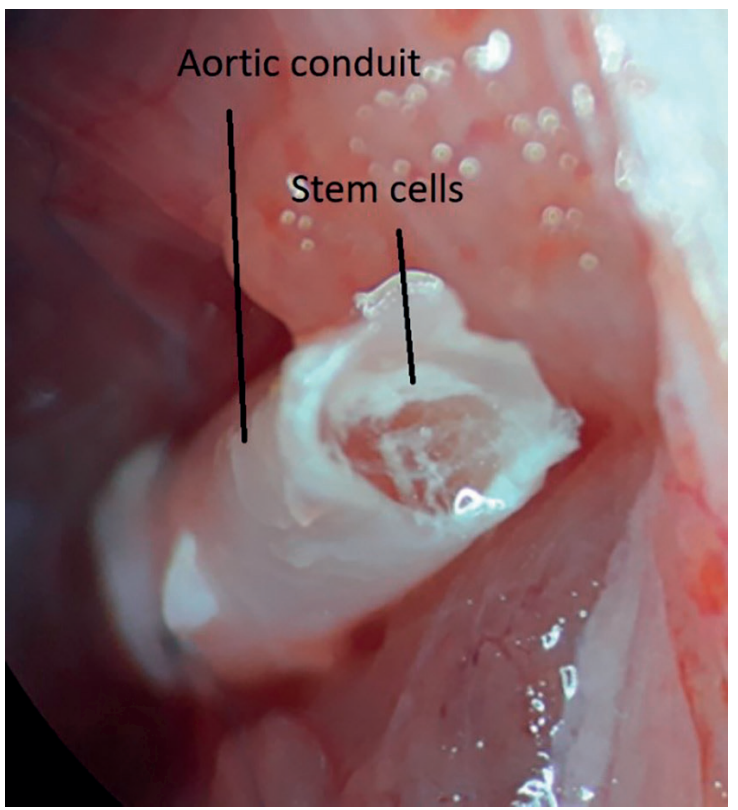

Stem cells inside the aortic conduit

\section{POSTOPERATIVE TREATMENT. NERVE REGENERATION EVALUATION}

All the rats in the 4 batches received antibiotic prophylaxis with enroxil $0.003 \mathrm{mg} / \mathrm{kg}$ subcutaneous for 3 days (first dose at the end of the procedure, the latter 2 doses in days 1 and 2 post operatory). For analgesia and an anti-inflammatory response, meloxicam $1 \mathrm{mg} /$ $\mathrm{kg}$ was used for 3 consecutive days.

All rats were clinically evaluated every other week until the $12^{\text {th }}$ week, when they were euthanized. The sciatic nerve being a mixt nerve, the evaluation was both sensitive as well as motor.

For the sensitive evaluation, a cage with metal grills was used in order to perform the pinch test. The operated limb was pinch at 3 different sites with an anatomic forceps and graded as following:

- 3 points - limb retraction when stimulus applied in the plantar region (the metatarsal area);

- 2 points - limb retraction when stimulus applied at the ankle;

- 1 point - limb retraction when stimulus applied at the calf area;

- 0 points - no retraction at any above given stimulus.

The motor function was also evaluated and marked as following:

- 3 points - abduction and finger extension;

- 2 points - only finger abduction;

- 1 point - flexion or minimal movements;

- 0 points - no movements.

Another test for nerve regeneration was the evaluation of the footprints. For this, 2 plastic cages were united via a cuboid semitransparent plastic tube, opened at the bottom, where an A3 paper was placed. At the entrance in the tube, an ink pad was placed so that the rats would walk on it before running along the plastic tube.

The footprint test was useful to calculate the sciatic functional index (SFI) after the Bain and MacKinnon formula, which takes into account 3 parameters plantar length (between the heel and the longest toe), the intermediary interdigital length (between the $2^{\text {nd }}$ and $4^{\text {th }}$ toe) and the maximum interdigital distance (between $1^{\text {st }}$ and $5^{\text {th }}$ toe) ${ }^{34}$.

To calculate this index, values from both operated and non-operated limb were necessary: 


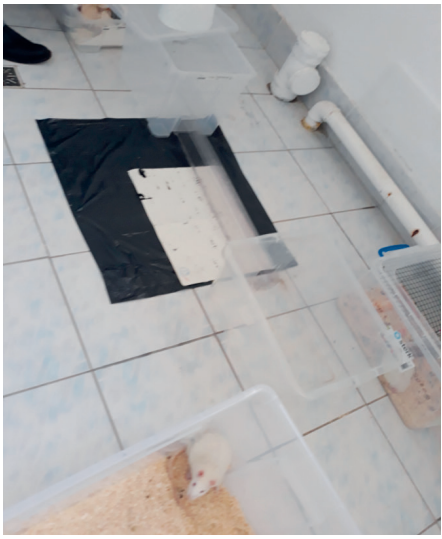

Tunnel

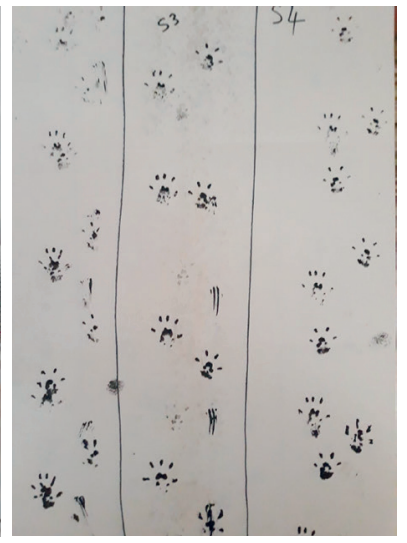

Footprint test
- EPL - plantar length on operated limb;

- NPL - plantar length on non-operated limb;

- EIT - intermediary interdigital length on operated limb;

- NIT - intermediary interdigital length on nonoperated limb;

- ETS - maximum interdigital distance on operated limb;

- NTS - maximum interdigital distance on nonoperated limb.

The sciatic functional index can be calculated after the formula: $\mathrm{SFI}=-38.3 \times \mathrm{EPL}-\mathrm{NPL} / \mathrm{NPL}+\mathbf{1 0 9 . 5} \mathrm{x}$ ETS-NTS/NTS+ $13.3 \times$ EIT-NIT/NIT - 8.8.

The normal value of this index has the 0 value (in case of a perfectly normal function), while -100 represents total loss of function. The 0 value was attributed to the left non-operated limb.

At 12 weeks after the operation, all rats were sacrificed in order to harvest the gastrocnemius muscles bilaterally and the right sciatic nerve for histologic examination. The euthanasia protocol consisted of an overdose of the anesthetic solution (ketamine $200 \mathrm{mg} /$ $\mathrm{kg}$ and xylazine $20 \mathrm{mg} / \mathrm{kg}$ ), injected intraperitoneally, followed by a direct intracardiac injection of $\mathrm{KCl}$. This induced a hyperkalemia, consequently altering the cardiac contractility and exitus via cardiac arrest.

\section{RESULTS}

42 male rats were used for the study. 2 were sacrificed in order to harvest biologic materials (PRP and aortic conduits). The 40 rats were equally divided into the 4 research groups. All rats were operated on the right sciatic nerve.
2 rats from the first group were excluded from the study, one due to postoperative death, the other one due to nerve rupture. The rat with the nerve rupture was kept for the duration of the study (12 weeks) in order to compare the final results of nerve regeneration after nerve repair to the situation in which no repair was performed.

The biostatistics was done using SPSS. For the analysis of the continuous variables non-parametric tests were performed (for the variables without normal distribution) - Median test. For this type of data, the median and Inter Quartile Range (IQR) were reported.

The threshold for statistical significance was $\mathrm{p}<0.05$. The analysis for the ordinal variables was done using the Likehood Ration test, the results being reported as percentages. The correlation between the continuous non-parametric variables was done using the Kendall Tau b test. The graphic representation was done using box-plot graphics, columns, scatter-dot and line.

Sensitivity, motor function and SFI at 12 weeks

\begin{tabular}{|l|c|c|c|c|c|}
\hline \multicolumn{1}{|c|}{$\mathbf{n = 3 8}$} & Batch 1 & Batch 2 & Batch 3 & Batch 4 & Total \\
\hline Variable & $\begin{array}{l}\text { Medi- } \\
\text { an(IQR) }\end{array}$ & $\begin{array}{l}\text { Medi- } \\
\text { an(IQR) }\end{array}$ & $\begin{array}{l}\text { Medi- } \\
\text { an(IQR) }\end{array}$ & $\begin{array}{l}\text { Medi- } \\
\text { an(IQR) }\end{array}$ & $\begin{array}{l}\text { Medi- } \\
\text { an(IQR) }\end{array}$ \\
\hline $\begin{array}{l}\text { Sensitivity } \\
\text { at 12 weeks }\end{array}$ & $3(0)$ & $3(0)$ & $3(0)$ & $3(0)$ & $3(0)$ \\
\hline $\begin{array}{l}\text { Motor } \\
\text { function at } \\
\text { 12 weeks }\end{array}$ & $2.5(1)$ & $2(2)$ & $2(1)$ & $2(1)$ & $2(1)$ \\
\hline $\begin{array}{l}\text { SFI at 12 } \\
\text { weeks }\end{array}$ & -57.5 & $\begin{array}{c}-58.5 \\
(12)\end{array}$ & $\begin{array}{c}-55.5 \\
(10)\end{array}$ & $-57(5)$ & $-57(6)$ \\
\hline
\end{tabular}

Median test for sensitivity, motor function and SFI at 12 weeks

\begin{tabular}{|l|c|c|}
\hline \multicolumn{1}{|c|}{ Variable } & $\begin{array}{c}\text { Median test } \\
\text { (Degree of freedom) }\end{array}$ & P value \\
\hline Sensitivity at 12 weeks & - & - \\
\hline $\begin{array}{l}\text { Motor function at 12 } \\
\text { weeks }\end{array}$ & $0.7(3)$ & 0.862 \\
\hline SFI at 12 weeks & $2(3)$ & 0.572 \\
\hline
\end{tabular}


Sensitivity at 12 weeks had a maximum result for all 4 batches, without any difference. The motor function at 12 weeks had the best result in the nerve graft batch, followed by the other 3 batches without significant statistical differences.

The sciatic functional index at 12 weeks presented similar results among the 4 groups, with best results in the PRP group, followed by the stem cell group, then the nerve graft and last being the simple aortic conduit batch.

Sensitivity test analysis - comparison between the 4 batches in evolution

\begin{tabular}{|c|c|c|c|c|c|}
\hline n=38 & Batch 1 & Batch 2 & Batch 3 & Batch 4 & Total \\
\hline Variable & $\begin{array}{c}\text { Medi- } \\
\text { an(IQR) }\end{array}$ & $\begin{array}{c}\text { Medi- } \\
\text { an(IQR) }\end{array}$ & $\begin{array}{c}\text { Medi- } \\
\text { an(IQR) }\end{array}$ & $\begin{array}{c}\text { Medi- } \\
\text { an(IQR) }\end{array}$ & $\begin{array}{c}\text { Medi- } \\
\text { an(IQR) }\end{array}$ \\
\hline $\begin{array}{c}\text { Sensitivity } \\
\text { at 2 weeks }\end{array}$ & $1(0)$ & 0 & $1(1)$ & $1(1)$ & $1(1)$ \\
\hline $\begin{array}{c}\text { Sensitivity } \\
\text { at 4 weeks }\end{array}$ & $1(1)$ & $1(1)$ & $1(0)$ & $1(0)$ & $1(0)$ \\
\hline $\begin{array}{c}\text { Sensitivity } \\
\text { at 6 weeks }\end{array}$ & $2(1)$ & $1(1)$ & $2(0)$ & $2(1)$ & $2(0)$ \\
\hline $\begin{array}{c}\text { Sensitivity } \\
\text { at 8 weeks }\end{array}$ & $2(1)$ & $2(0)$ & $2(1)$ & $2(0)$ & $2(0)$ \\
\hline $\begin{array}{c}\text { Sensitivity } \\
\text { at 10 weeks }\end{array}$ & $2(1)$ & $2(1)$ & $3(0)$ & $3(1)$ & $3(1)$ \\
\hline $\begin{array}{c}\text { Sensitivity } \\
\text { at 12 weeks }\end{array}$ & $3(0)$ & $3(0)$ & $3(0)$ & $3(0)$ & $3(0)$ \\
\hline
\end{tabular}

Median test for sensitivity evaluation

\begin{tabular}{|l|l|l|}
\hline Variable & $\begin{array}{l}\text { Median test } \\
\text { (Degree of freedom) }\end{array}$ & P value \\
\hline Sensitivity at 2 weeks & $3.851(3)$ & 0.278 \\
\hline Sensitivity at 4 weeks & $7.917(3)$ & 0.05 \\
\hline Sensitivity at 6 weeks & $3.851(3)$ & 0.278 \\
\hline Sensitivity at 8 weeks & $3.254(3)$ & 0.354 \\
\hline Sensitivity at 10 weeks & - & - \\
\hline Sensitivity at 12 weeks & - & - \\
\hline
\end{tabular}

For the $10^{\text {th }}$ and $12^{\text {th }}$ week evaluation, all values are smaller or equal to the median; therefore the test cannot be applied.

The tables above prove that the best sensitivity recovery is among the PRP batch at 10 weeks (without any statistical difference).
Motor function analysis - comparison between the 4 batches in evolution

\begin{tabular}{|l|l|l|l|l|l|}
\hline n=38 & Batch 1 & Batch 2 & Batch 3 & Batch 4 & Total \\
\hline Variable & $\begin{array}{l}\text { Median } \\
\text { (IQR) }\end{array}$ & $\begin{array}{l}\text { Median } \\
\text { (IQR) }\end{array}$ & $\begin{array}{l}\text { Median } \\
\text { (IQR) }\end{array}$ & $\begin{array}{l}\text { Median } \\
\text { (IQR) }\end{array}$ & $\begin{array}{l}\text { Median } \\
\text { (IQR) }\end{array}$ \\
\hline $\begin{array}{l}\text { Motor } \\
\text { function } \\
\text { at 2 weeks }\end{array}$ & 0 & 0 & 0 & 0 & 0 \\
\hline $\begin{array}{l}\text { Motor } \\
\text { function } \\
\text { at 4 weeks }\end{array}$ & 0 & 0 & 0 & 0 & $1(0)$ \\
\hline $\begin{array}{l}\text { Motor } \\
\text { function } \\
\text { at 6 weeks }\end{array}$ & $1(1)$ & $0(1)$ & $1(0)$ & $1(1)$ \\
\hline $\begin{array}{l}\text { Motor } \\
\text { function } \\
\text { at 8 weeks }\end{array}$ & $1(1)$ & $1(2)$ & $1(1)$ & $1.5(1)$ & $1(1)$ \\
\hline $\begin{array}{l}\text { Motor } \\
\text { function } \\
\text { at 10 } \\
\text { weeks }\end{array}$ & $2(2)$ & $1.5(1)$ & $2(1)$ & $2(0)$ & $2(1)$ \\
\hline $\begin{array}{l}\text { Motor } \\
\text { function } \\
\text { we 12 } \\
\text { weeks }\end{array}$ & $2.5(1)$ & $2(2)$ & $2(1)$ & $2(1)$ & 0 \\
\hline
\end{tabular}

Median test for sensitivity evaluation

\begin{tabular}{|l|l|l|}
\hline Variable & $\begin{array}{l}\text { Median Test (Degree of free- } \\
\text { dom) }\end{array}$ & P value \\
\hline $\begin{array}{l}\text { Motor function at 2 } \\
\text { weeks }\end{array}$ & $3.851(3)$ & 0.278 \\
\hline $\begin{array}{l}\text { Motor function at 4 } \\
\text { weeks }\end{array}$ & $3.851(3)$ & 0.278 \\
\hline $\begin{array}{l}\text { Motor function at 6 } \\
\text { weeks }\end{array}$ & $2.401(3)$ & 0.493 \\
\hline $\begin{array}{l}\text { Motor function at } 8 \\
\text { weeks }\end{array}$ & $2.122(3)$ & 0.547 \\
\hline $\begin{array}{l}\text { Motor function at 10 } \\
\text { weeks }\end{array}$ & $0.749(3)$ & 0.862 \\
\hline $\begin{array}{l}\text { Motor function at 12 } \\
\text { weeks }\end{array}$ & $4.994(3)$ & 0.172 \\
\hline
\end{tabular}

The best nerve recovery when analyzing motor function can be seen in the nerve graft batch. The median of the test showed no statistical differences between the batches.

\section{Sciatic functional index (SFI)}

Determining the SFI was done starting with the $6^{\text {th }}$ week because prior to this time the footprints could not be fairly evaluated. 
SFI analysis - comparison between the 4 batches in evolution

\begin{tabular}{|l|l|l|l|l|l|}
\hline n=38 & Batch 1 & Batch 2 & Batch 3 & Batch 4 & Total \\
\hline Variable & $\begin{array}{l}\text { Medi- } \\
\text { an(IQR) }\end{array}$ & $\begin{array}{l}\text { Medi- } \\
\text { an(IQR) }\end{array}$ & $\begin{array}{l}\text { Medi- } \\
\text { an(IQR) }\end{array}$ & $\begin{array}{l}\text { Medi- } \\
\text { an(IQR) }\end{array}$ & $\begin{array}{l}\text { Medi- } \\
\text { an(IQR) }\end{array}$ \\
\hline $\begin{array}{l}\text { SFI at 6 } \\
\text { weeks }\end{array}$ & $-75.5(8)$ & $-76(9)$ & $-76(7)$ & $-76.5(4)$ & $-76(4)$ \\
\hline $\begin{array}{l}\text { SFI at 8 } \\
\text { weeks }\end{array}$ & $-69.5(6)$ & $\begin{array}{l}-70.5 \\
(11)\end{array}$ & $-69(7)$ & $-69.5(4)$ & $-69.5(4)$ \\
\hline $\begin{array}{l}\text { SFI } \\
\text { at 10 } \\
\text { weeks }\end{array}$ & $-63.5(7)$ & $-64(12)$ & $-62(6)$ & $-62(5)$ & $-62.5(4)$ \\
\hline $\begin{array}{l}\text { SFI } \\
\text { at 12 } \\
\text { weeks }\end{array}$ & $-57.5(9)$ & $\begin{array}{l}-58.5 \\
(12)\end{array}$ & $\begin{array}{l}-55.5 \\
(10)\end{array}$ & $-57(5)$ & $-57(6)$ \\
\hline
\end{tabular}

Median test for SFI evaluation

\begin{tabular}{|l|l|l|}
\hline Variable & Median Test(Degree of freedom) & P value \\
\hline SFI at 6 weeks & $1.08(3)$ & 0.782 \\
\hline SFI at 8 weeks & $0.8(3)$ & 0.849 \\
\hline SFI at 10 weeks & $0.8(3)$ & 0.849 \\
\hline SFI at 12 weeks & $2(3)$ & 0.572 \\
\hline
\end{tabular}

The footprint test showed an improvement in all 4 batches. The best results at 12 weeks were recorded in the PRP batch, followed by the stem cell batch, then the nerve graft batch and finally the simple aortic conduit batch.

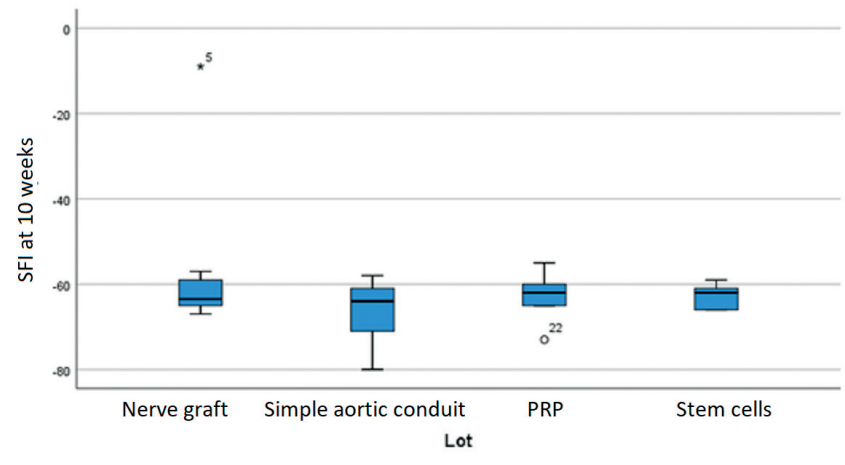

Graphic distribution of SFI at 10 weeks for each batch

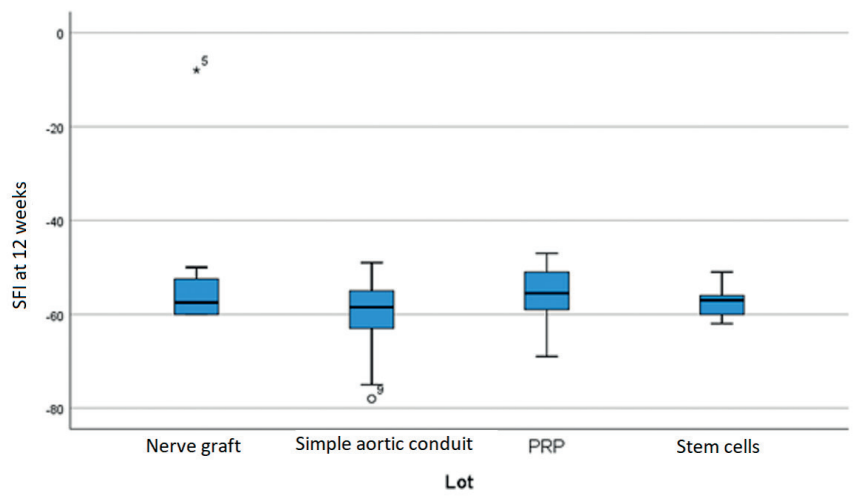

Graphic distribution of SFI at 12 weeks for each batch

\section{DISCUSSIONS}

The nerve graft is considered gold standard when repairing a nerve defect. There are several issues to be considered both in research and in clinical practice when using nerve grafts. Great suture tension, incorrect alignment, lack of symmetry of the nerve endings can all lead to a poor result ${ }^{35}$. Improper traction may harm the noble tissue, while passing the needle too profound or tying the knot too firm may create a misalignment, with axoplasmatic protrusion ${ }^{36}$.

Great attention was paid to selecting the correct area where the incisions were placed, realizing a proper dissection, correct nerve identification and choosing the proper place where to make the incision in the sciatic nerve in order to create a nerve graft.

Using a biological nerve conduit poses the problem of right conservation, in order to preserve its properties for a longer period of time. Ringer solution was described in a study by Matos et al as a proper conservation solution for splenic tissue, which could be implanted after 24 hours at the level of the greater omentum, preserving its structural morphology as well as a good functional regeneration ${ }^{37}$.

Choosing the right nervous conduit is done taking into consideration the diameter of the injured nerve, as well as the length of the defect. There are situations in which, to obtain a longer range for nerve defects, the surgeon could also combine nerve grafting and nerve conduits. Francel et al demonstrated in a study the benefits of using a nerve graft inside a silicon conduit in comparison to the silicon conduit used alone ${ }^{38}$. 
Although the rat aorta was a suitable choice to use as a nerve conduit, it did have some disadvantages. Firstly it required the euthanasia of the 2 extra rats (which were also used to harvest PRP). Secondly, there was also the risk of reject (as it was an allograft which could generate an immune reaction). Thirdly, being a biologic material, there was a great need to be conserved for several days in order to be used for multiple surgical interventions.

For the immune reaction, administrating immunosuppression medicine could prevent this problem, with the risk of increasing infection. Therefore, the option was to administer immunosuppression medicine only in case of clinical manifestation of graft rejection (which never occurred). One explanation for this could be the fact that the immune system is different in humans and in rats - rodents present in majority lymphocytes, while humans present neutrophils ${ }^{39}$.

The Ringer solution was appropriate to conserve the aorta up to one week at $4^{\circ} \mathrm{C}$, without macroscopic differences. Preserving biological conduits usually require a tissue bank with special conditions. Glycerol solution $15 \%$ is an optimal preservation environment; this has been proved useful for both skin grafts as well as corneal tissue ${ }^{40,41}$.

As for PRP and stem cells used in nerve regeneration, Quertainmont et al support this idea, PRP having slight better results compared to stem cells. The same study mitigates for a combined use of the 2 substances, this combination having higher results compared to each of them used separately ${ }^{42}$. Teymor et al added thrombine to the PRP solution to achieve better results ${ }^{43}$.

The original idea to obtain the stem cells was by harvesting adipose cells. This idea had some limitations: increasing the morbidity and operating times, increasing the anesthesia doses and having small quantities of adipose tissue which could be harvested from young rats. For these reason, human stem cells (xenografts) were harvested from the umbilical cord and preserved in liquid nitrogen. One important advantage of these stem cells was the ease of use.

The clinical measurements were performed periodically in small time frames in order to have a better representation of the regenerative process.

\section{CONCLUSIONS}

In vivo nerve repair represents the most accurate evaluation of special nerve repair techniques. Right anesthesia, correct protocols before starting and experience in the field of microsurgery are the premises of a properly conducted experiment. Even though the study didn't have statistical power due to the small number of rats used in the 4 groups, some conclusions can be drawn and may be subject to further research.

Although the nerve graft achieved the best results when referring to overall motor function (from the clinical perspective), the PRP group had the best results in prevention muscle atrophy (indicated by the gastrocnemius index), as well as the best results obtained in the periodical sensitivity tests. This makes the PRP with a nerve conduit a suitable replacement for the traditional nerve graft.

The stem cells group also provided good results in preventing muscle atrophy, above the nerve graft batch. However these cells are difficult to obtain and may implicate legal aspects if they were to be used in humans.

The simple aortic nerve graft had the poorest results, both when referring to sensitivity and motor function. For this reason, adding different types of substances or tissues inside the nerve conduit (such as PRP or stem cells) could make a significant difference in the final results.

Compliance with ethics requirements: The authors declare no conflict of interest regarding this article. The authors declare that all the procedures and experiments of this study respect the ethical standards in the Helsinki Declaration of 1975, as revised in 2008(5), as well as the national law. Informed consent was obtained from all the patients included in the study. 


\section{References}

1. Kornfeld T, Vogt PM, Radtke C. Nerve grafting for peripheral nerve injuries with extended defect sizes. Wien Med Wochenschr. 2019 Jun;169(9-10):240-251. doi: 10.1007/s10354-018-0675-6. Epub 2018 Dec 13. Review

2. Mihai Mehedintu-Ionescu, Ovidiu Stefanescu, Radu Cristian Jecan. Nervous Regeneration Allograph Type of Periferic Nerv. Modern Medicine I 2019, Vol. 26, No. 2

3. Özkan HS, Karataş Silistreli Ö, Ergür B, İrkören S. Repairing peripheral nerve defects by vein grafts filled with adipose tissue derived stromal vascular fraction: an experimental study in rats. Ulus Travma Acil Cerrahi Derg. 2016 Jan;22(1):7-11. doi: 10.5505/tjtes.2015.12612.

4. Gu LQ, Zhu JK. Repair of different sized nerve defects using degenerated muscle grafts with vascular implantation: an experimental study in the rat. J Reconstr Microsurg. 1992 Jan;8(1):47-52.

5. Le ADK, Enweze L, DeBaun MR, Dragoo JL. Current Clinical Recommendations for Use of Platelet-Rich Plasma. Curr Rev Musculoskelet Med. 2018 Dec; 11(4):624-634.

6. Andrei Marin, Georgiana Gabriela Marin, Anca Patea, Dan Mircea Enescu. Timing, Logistics and Bureaucratic Process in Planning an Experimental In Vivo Nerve Regeneration Project from A to Z. Modern Medicine I 2019, Vol. 26, No. 2

7. Costea Ruxandra, Daniel Lastofka, and Mihai Mehedințu. "Comparison of Ketamine-Medetomidine-butorphanol and Ketamine-dexmedetomidine-butorphanol Anesthesia in Rats." Agriculture and Agricultural Science Procedia 6 (2015): 305-308.

8. Mehedintu-Ionescu M., Costea, R., Balint, E., \& Lastofka, D. (2017). Surgery technique models of sciatic nerve allograph in Wistar rats. Abstracts/Journal of Biotechnology 256S, 44, S116

9. Marin Andrei, Mihai Ruxandra Ioana, Marin Georgiana Gabriela. Pitfalls and problems encountered in rat model sciatic nerve surgery. Romanian Neurosurgery (2019) XXXIII (4): pp. 396399DOI: 10.33962/roneuro-2019-064

10. Le ADK, Enweze L, DeBaun MR, Dragoo JL. Current Clinical Recommendations for Use of Platelet-Rich Plasma. Curr Rev Musculoskelet Med. 2018 Dec; 11(4):624-634.

11. Ikumi A, Hara Y, Yoshioka T, Kanamori A, Yamazaki M. Effect of local administration of platelet-rich plasma (PRP) on peripheral nerve regeneration: An experimental study in the rabbit model. Microsurgery. 2018 Mar;38(3):300-309. Doi: 10.1002/ micr.30263. Epub 2017 Nov 2.

12. Teymur $H$, Tiftikcioglu $Y O$, Cavusoglu T, Tiftikcioglu Bl, Erbas $\mathrm{O}$, Yigitturk G, Uyanikgil Y. Effect of platelet-rich plasma on reconstruction with nerve autografts. Kaohsiung J Med Sci. 2017 Feb;33(2):69-77. doi: 10.1016/j. kjms.2016.11.005. Epub 2016 Dec 29

13. Sánchez M, Anitua E, Delgado D, Sanchez P, Prado R, Orive G, Padilla S. Platelet-rich plasma, a source of autologous growth factors and biomimetic scaffold for peripheral nerve regeneration. Expert Opin Biol Ther. 2017 Feb;17(2):197-212. Doi: 10.1080/14712598.2017.1259409. Epub 2016 Nov 28. Review

14. Bastami F, Vares P, Khojasteh A. Healing Effects of Platelet-Rich Plasma on Peripheral Nerve Injuries. J Craniofac Surg. 2017 Jan;28(1):e49-e57. doi: 10.1097/SCS.0000000000003198. Review.

15. Conley CL. Hemostasis. In: Mountcastle VB, editor. Medical Physiology. St. Louis: The C.V. Mosby Company; 2004. pp. 113746. [Google Scholar] [Ref list]

16. Harrison P, Cramer EM. Review Platelet alpha-granules. Blood Rev. 1993 Mar; 7(1):52-62.
17. Schilephake H. Review Bone growth factors in maxillofacial skeletal reconstruction. Int J Oral Maxillofac Surg. 2002 Oct; 31(5):469-84.

18. Sunitha Raja V, Munirathnam Naidu E. Review Platelet-rich fibrin: evolution of a second-generation platelet concentrate. Indian J Dent Res. 2008 Jan-Mar; 19(1):42-6.

19. Cole BJ, Seroyer ST, Filardo G, Bajaj S, Fortier LA. Platelet-rich plasma: where are we now and where are we going? Sports Health. 2010 May; 2(3):203-10.

20. Dhurat R, Sukesh M. Principles and Methods of Preparation of Platelet-Rich Plasma: A Review and Author's Perspective. J Cutan Aesthet Surg. 2014 Oct-Dec;7(4):189-97. doi: 10.4103/09742077.150734. Review.

21. Chen CJ, Ou YC, Liao SL, et al. Transplantation of bone marrow stromal cells for peripheral nerve repair. Exp Neurol. 2007; 204 $443-453$.

22. Wang, J., Ding, F., Gu, Y., Liu, J., Gu, X., 2009. Bone marrow mesenchymal stem cells promote cell proliferation and neurotrophic function of Schwann cells in vitro and in vivo. Brain Res. 1262, 7-15.

23. Borlongan, C.V., Lind, J.G., Dillon-Carter, O., Yu, G., Hadman, M., Cheng, C., Carroll, J., Hess, D.C., 2004. Bone marrow grafts restore cerebral blood flow and blood brain barrier in stroke rats. Brain Res. 1010, 108-116.

24. Chopp, M., Li, Y., 2002. Treatment of neural injury with marrow stromal cells. Lancet Neurol. 1, 92-100. Chopp, M., Zhang, X.H., Li, Y., Wang, L., Chen, J., Lu, D., Lu, M., Rosenblum, M., 2000. Spinal cord injury in rat: treatment with bone marrow stromal cell 180olecular180- tation. Neuroreport 11, 3001-3005

25. Crigler, L., Robey, R.C., Asawachaicharn, A., Gaupp, D., Phinney, D.G., 2006. Human mesenchymal stem cell subpopulations express a variety of neuro-regulatory molecules and promote neuronal cell survival and neuritogenesis. Exp. Neurol. 198, 54-64.

26. Gu, Y., Wang, J., Ding, F., Hu, N., Wang, Y., Gu, X., 2010. Neurotrophic actions of bone marrow stromal cells on primary culture of dorsal root ganglion tissues and neurons. J. Mol. Neurosci. 40, 332-341.

27. Hofstetter, C.P., Schwarz, E.J., Hess, D., Widenfalk, J., El Manira, A., Prockop, D.J., Olson, L., 2002. Marrow stromal cells form guiding strands in the injured spinal cord and promote recovery. Proc. Natl. Acad. Sci. U.S.A. 99, 2199-2204.

28. Munoz, J.R., Stoutenger, B.R., Robinson, A.P., Spees, J.L., Prockop, D.J., 2005. Human stem/progenitor cells from bone marrow promote neurogenesis of endogenous neural stem cells in the hippocampus of mice. Proc. Natl. Acad. Sci. U.S.A. 102, 1817118176.

29. Caplan, A.I., Dennis, J.E., 2006. Mesenchymal stem cells as trophic mediators. J. Cell. Biochem. 98, 1076-1084

30. Neuhuber, B., Timothy Himes, B., Shumsky, J.S., Gallo, G., Fischer, I., 2005. Axon growth and recovery of function supported by human bone marrow stromal cells in the injured spinal cord exhibit donor variations. Brain Res. 1035, 73-85.

31. Chen, X., Li, Y., Wang, L., Katakowski, M., Zhang, L., Chen, J., Xu, Y., Gautam, S.C., Chopp, M., 2002. Ischemic rat brain extracts induce human marrow stromal cell growth factor production. Neuropathology 22, 275-279.

32. Lascar I., Zamfirescu D. Microchirurgie experimentala, 2000, 3437

33. Mehta R, Baranova A, Birerdinc A. Do-It-Yourself device for recovery of cryopreserved samples accidentally dropped into cryogenic storage tanks. J Vis Exp. 2012;(63):e3903. Published 2012 May 11. doi:10.3791/3903 
34. Bain JR, Mackinnon SE, Hunter DA. Functional evaluation of complete sciatic, peroneal, and posterior tibial nerve lesions in the rat. Plast Reconstr Surg. 1989;83:129-138.

35. Ducic I, Safa B, DeVinney E. Refinements of nerve repair with connector-assisted coaptation. Microsurgery. 2017 Mar;37(3):256-263. doi: 10.1002/micr.30151. Epub 2016 Dec 30. Review

36. Andrei MARIN, Ruxandra Ioana MIHAI, Georgiana Gabriela MARIN. Tips and Tricks in Experimental Nerve Defect Surgery. Modern Medicine I 2020, Vol. 27, No. 1

37. Matos Filho AS, Petroianu A, Cardoso VN, Vidigal PVT. Splenic implant preservation after conservation in lactated Ringer's solution. Rev Col Bras Cir. 2018;45(1):e1346. doi: 10.1590/01006991e-20181346. Epub 2018 Feb 15. Portuguese, English

38. Francel PC, Francel TJ, Mackinnon SE, Hertl C. Enhancing nerve regeneration across a silicone tube conduit by using interposed short-segment nerve grafts. J Neurosurg. 1997 Dec;87(6):88792
39. Mestas J, Hughes CC. Of mice and not men: differences between mouse and human immunology. J Immunol. 2004 Mar 1;172(5):2731-8. Review.

40. Gupta N, Upadhyay P. Use of glycerol-preserved corneas for corneal transplants. Indian J Ophthalmol. 2017 Jul;65(7):569573. doi: 10.4103/ijo.IJO_56_17.

41. Kim SW, Choi IK, Lee JH, Ahn ST, Rhie JW. Treatment of necrotising fasciitis using glycerol-preserved skin allografts for temporary wound coverage. J Wound Care. 2014 Feb;23(2 Suppl):S20-2.

42. Quertainmont R, Cantinieaux D, Botman O, Sid S, Schoenen J, Franzen R (2012) Mesenchymal Stem Cell Graft Improves Recovery after Spinal Cord Injury in Adult Rats through Neurotrophic and Pro-Angiogenic Actions. PLoS ONE 7(6): e39500

43. Teymur H, Tiftikcioglu Y, Cavusoglu T, Tiftikcioglu B, Erbas O, Yigitturk $\mathrm{G}$ et al. Effect of platelet-rich plasma on reconstruction with nerve autografts. The Kaohsiung Journal of Medical Sciences. 2017;33(2):69-77. 